\title{
The Approach to Sexual Orientation in Schools: Teachers' Views
}

\author{
Cláudio Machado, Fátima Coelho \\ Universidade Fernando Pessoa, Porto, Portugal
}

\begin{abstract}
This research wants to describe and understand the views of teachers in the Azores (Portugal) on sexual orientation, what they feel and intend to do about the approach to the subject and the obstacles they believe they need to overcome in order to do so. The study was descriptive and quantitative in approach. A questionnaire, which was answered by 394 teachers, was used as the data collection tool.

After analysing the results, it was concluded that the variables that are associated with teachers' views on sexual orientation are gender, length of service, participation in training on sexual orientation or training which has involved this subject, and having a close relationship with someone who is openly lesbian, gay or bisexual.

Most teachers have, positive views about sexual orientation, as well as adequate knowledge on the subject, and feel prepared and intend to address the subject. However, this does not imply that they approach and put their knowledge into practice appropriately. Furthermore, there are obstacles to doing this, the greatest being the threat of homophobia and heterosexism, which may come from the social and family environment of the student. On the other hand, professional experience, has an important role in the recognition of the diversity of sexual orientations on people with disabilities and the training sessions on sexual orientation or that have involved this subject, which have been in a general way, attended by teachers, have not been able to transform more positively their assumptions on sexual orientation in comparison to the assumptions of teachers who did not participate in these sessions.
\end{abstract}

\section{Introduction}

Currently, in Portugal, sex education is mandatory in schools and must meet goals in regard to the concept of sexual orientation at all educational levels and for all students.

The sexual orientation of each individual begins to be defined very early, as soon as early childhood and may vary throughout life, not following any evolutionary order. The prejudice of Portuguese society in relation to homosexuality and bisexuality leads to people who are in this condition often being discriminated against.
Discrimination at school often in the form of homophobic bullying can cause very serious damage in the life of young people, such as depression, isolation, loneliness and suicide, these phenomena having a greater incidence in gays and lesbians in comparison to young heterosexual people. Currently, sexual education is compulsory in schools and must meet goals relating to the concept of sexual orientation at all levels of education and for all students without exception.

Thus it seems relevant to study the issue of how to approach sexual orientation in schools, within the context of sex education, we decided, in line with current thinking and as an overall objective, to describe and understand the views and knowledge of teachers in the Azores on sexual orientation. We also explored what they feel and how they intend to approach this issue in schools, as part of sex education, and what obstacles they believe they need to overcome. At the same time we sought to determine whether the following variables are correlated with teachers' views on sexual orientation: gender, age, type of recruitment, academic qualifications, years of service, training on sexual orientation or training which has involved this subject, having a close relationship with someone who is openly LGB (lesbian, gay or bisexual), preparedness in terms of the approach to the subject and degree to which they intend to address the issue.

As any teacher may potentially teach any student, this research was focused on all teachers, regardless of the type of recruitment to which they were subject to.

This work is based on the belief that it is time to join efforts to ensure an optimized commitment, in order to improve the approach of sexual orientation in schools, since this area has been neglected and the health of people is at stake, the essence of their lives, equality in difference.

\section{Theoretical context}

Today, it is argued that sexuality is present in all aspects of human life, from conception to natural death, manifesting itself in all phases of life, including childhood and adolescence, without distinction as to race, gender, disability or other particularities. Sexuality is a way of feeling and 
expression of the human being, through affectivesexual relationships where the affective relationships and the sexual relationships (not only genital) do not complete themselves alone, but as a whole complete the concept of sexuality.

Schooling and sexual education is a right for all, and in line with the principles of inclusive schooling all teachers, whether involved in special education or not, have to cater to all students [1].

In the Azores, sex education in schools is mandatory and must comply with the concept of sexual orientation at all levels of education [2]. Moreover, it may be delivered by teachers of any subject.

Sexuality is a common need to every human being and an essential component at all stages of life [3]. It manifests itself in many ways and is often denied and neglected for the disabled, due to unpreparedness and prejudice in society. Sexuality can be understood "as a mixed set that contains contact, corporal relationship, psychic, sentiments, desire oriented to people and objects; dreams and delusions; pleasure, enjoyment and pain; loss, suffering and frustration; growth and future; consciousness, the fullness of the present and the memory of the past; these processes that are being prepared and give rise to new achievements"[4]. Sexual orientation begins to be defined at a very young age, in early childhood [5] and contrary to what many may think, is not fixed and immutable. It is fluid and does not obey any developmental order. It can be redefined in any way over the course of a lifetime [6], [7]. This condition is identical for individuals with or without disabilities [5], [8], [9]. However, women admit to more homosexual or bisexual experiences than men, and younger and highly educated women admit to having such experiences [10].

Homosexuality, heterosexuality and bisexuality are considered sexual orientations that differentiate themselves through sex or by the gender that each individual feels attraction throughout life a homosexual individual feels physical, psychological and emotional attraction for another individual of the same sex, while heterosexual individuals feel it for people of the opposite sex. Bisexual individuals may feel physical, psychological and emotional attraction for both genders, masculine and feminine.

Regardless of the sexual orientation of each individual i.e., sex or sexes for which they feel attracted to, the capacity to love, fall in love, establish stabile long lasting relationships are the same. Homosexual, bisexual and heterosexual individuals equally vary in values, personalities, attitudes, mannerisms, tastes, backgrounds and education. The only characteristic that distinguishes them consists of their focus of physical, psychological and emotional attraction [11]. Although there are no conclusive studies on the cause of different sexual orientations, some conclusions suggest that the sexual orientation of an individual may be determined by multiple factors of an environmental and biological character [11].

Prejudice in Portuguese society towards homosexuality and bisexuality leads people who fall into this category to be discriminated against [12]. However, having contact with people who are openly lesbian, gay or bisexual reduces prejudice towards them [5], [12]. The fact that sexual orientation is often passed over voluntarily by virtue of heterosexism and homophobia, does not help in reducing prejudice. [5] However, homophobia is higher in males [13].

Discrimination at school, often in the form of homophobic bullying, can cause very serious damage to the lives of young people, such as depression, isolation, loneliness and suicide, and these phenomena have a higher incidence in gays and lesbians than in heterosexual youth [5], [14]. In addition, we may have children, albeit heterosexual themselves, who have parents, relatives or close acquaintances who are homosexual or bisexual. They may even belong to families different from the heterosexual model [5], [15], [16]. This does not mean that the child will not have a healthy development [5], [16], even though there remains, in the general population, the opposite perception [16], [17], often causing unnecessary and harmful stress within the whole[16] family.

School has a fundamental role to play in sex education, along with the family and the rest of society. Sex education in schools is therefore of great importance for both students and their families [18] and this should be comprehensive and plural. [19]

Studies show that teachers' unpreparedness in the field of sexuality is significant and that their attitudes are also prejudiced and conservative in their outlook [3], [9], [18]. In addition, many teachers encounter obstacles which prevent them from putting into practice any kind of planned sexual education [18]. Despite this most teachers claim that they try to adopt a politically correct approach, in practice the little sex education they engage in is still mainly heterosexist and on purely biological aspects. However, teachers are often unaware of this [20].

The activities of the Eurobarometer, an initiative of the European Commission, enable the consultation and monitoring of public opinion in the countries of the European Union on different subjects and European issues. In comparison to the European average the Portuguese claimed to feel less at ease with the idea of having a homosexual neighbour and had lower probability of knowing or having as a friend a homosexual person. The majority of Portuguese $(58 \%)$ believe that sexual orientation is the main reason for discrimination in Portugal, ahead of ethnic origins and physical disability (both 57\%) and age $(53 \%)$. The percentage of Portuguese that 
point to sexual orientation as the main reason for discrimination is $9 \%$ higher than the average of the 27 European Union countries, where that type of discrimination appears only in fourth place $(47 \%)$, behind ethnic origins $(61 \%)$, age $(58 \%)$ and physical disability $(53 \%)$. The Mediterranean countries are those in which discrimination by sexual orientation is stronger: ahead of Portugal there is only Cyprus, Greece, Italy and France. In contrast, the countries which have recently joined the European Union seem to be the most tolerant: Bulgaria, Czech Republic, Slovakia and Estonia are the countries with the lowest percentages. In the case of Portugal, the percentage of people that admit knowing or relating to homosexuals is much lower than the European average: $21 \%$ compared to $38 \%$. In contrast, the percentage of Portuguese who relate to people of other faiths or religions, have friends of other sources or with some type of disability is within the European average. According to the study by António et al. [14] about homophobic bullying in the school context in Portugal it was seen that in line with international results school is the place where this phenomenon most occurs. The results show that the majority of young students have already witnessed homophobic bullying situations against others who are or who are thought to be homosexual or bisexual, most of these situations being witnessed within the school. The victims of homophobic bullying are mostly boys and suffer more psychological than physical violence. The following stand out as consequences of homophobic bullying: isolation, sadness and loneliness. The aggressive behaviors are often devalued and poorly controlled. Maia and Aranha [9] saw that training for teachers in the area of sex education had a shortcoming, this happens both with teachers of regular education as well as with teachers of special education. The majority of these teachers wrongly dismissed the sexuality of students in accordance to their own values. Studies conducted in Portugal allow us to conclude that the teachers had a diminished role as agents of formal sex education, in comparison to the sex education that was provided by parents, friends and colleagues and that the only subjects addressed by the teachers within the framework of sex education in a school context were AIDS and biological reproduction, revealing unbalanced, shallow and incomplete sex education practices. In addition to this, teachers were identified as sources of sex information by only $18 \%$ of the boys and $34 \%$ of the girls which indicates a certain negligence to carry out an effective sex education in a school context.

Teachers can and should help to change this situation by which this study intends to be a contribution to that change. It is necessary that the educational community, mainly teachers are sensitized to the need of sex education. As to the specific scheduling of subjects, these should emphasize not only the biological aspects of sexuality but also those linked to social and psychological aspects. The content should be approached without taboos and naturally as are the other curricular content, moreover, its approach should not be influenced by the personality, sensibility and values of the educator [18].

School has a fundamental role in sexual education, on a par with family and the rest of society, thus, sexual education is of great relevance in the school environment for both students and their families, even indirectly. Sex education must be comprehensive and diverse. Having said that and since, according to the legislation in force in Portugal, sex education in schools must be multidisciplinary and can be lectured by teachers from any area and for any student which they are responsible for, including students covered by the special education regime and integrated into regular education groups, it is pertinent to have as its study object all teachers and not just special education teachers, as well as, to explore and better understand in the context of the Azores, the factors which may be associated either at the base of the preparation or lack of preparation of the teachers to meet the needs of any student in the field of sexual education and for the theme of sexual orientation itself, as well as, the obstacles encountered by teachers to approach the subject in schools and the level of adequate knowledge, in accordance to the literature, that these same teachers have about the subject. In addition to that, and especially because there are few studies about the approach to sexual orientation in a school environment, namely in the Autonomous Region of the Azores, and those that exist have very small and not very diversified samples, it is important to encompass the largest number of teachers placed in public establishments in the territory of the Azores, in order to be able to better understand the issue, obtaining a more detailed and extended view about the problem and the factors associated with it.

It is the time, there is an urgent need to ensure optimized effort and commitment in order to improve the path to be traversed on the approach to sexual orientation in schools, since at stake is the essence of life of people, equality in difference.

\section{Methodology and procedures}

An online questionnaire was used as the data collection tool. The questionnaire was divided into three parts. The first part profiled the respondents and parts two and three functioned as a test to measure knowledge. For this, we turned to the aid of a comparison measurement unit that served as a reference. Two frames of reference were constructed, one for each part of the questionnaire. 
The questionnaire was validated by four experts, and a pretest was then applied to teachers not participating in the study sample. Once the design and testing of the research questionnaire was finished, with the collaboration of the Regional Secretariat for Azores Education and Culture, it was distributed via the official electronic mail to all teachers in post in state schools in the Azores.

Data from the questionnaire was processed quantitatively through the IBM SPSS software, version 21.0 for Windows. Quantitative variables were summarised through the mean \pm minimum and maximum standard deviation and the qualitative variables used absolute and relative frequencies. Analysis of the research hypothesis was carried out using the chi-square test and significance testing of the Spearman rank correlation coefficient. The differences are considered to be statistically significant to $\mathrm{p}<.05$.

\subsection{Target}

We limited the population to teachers in post in state schools in the Azores and we obtained the greatest sample possible using the snowball method. 394 teachers took part in the study.

We observed that $74.6 \%$ were female, with an average age of $39.0 \pm 7.4$ years; $88.8 \%$ had a first degree, and had an average length of service of 14.0 \pm 7.9 years; the most highly represented groups were: $28.3 \% 1^{\text {st }}$ Cycle teachers, $7.8 \%$ Mathematics, and $5.7 \%$ Portuguese as well as Mathematics/Natural Sciences. We also characterized the sample in accordance to the knowledge of LGB people, the preparation they felt they had and the intention of addressing sexual orientation to students and training on the subject.

Table 1. Knowledge of LGB people, preparation and the intention to address sexual orientation to students and training

\begin{tabular}{|c|c|c|c|}
\hline & \multirow{3}{*}{$\frac{\mathrm{N}}{222}$} & \multirow{3}{*}{$\begin{array}{c}\% \\
56,3 \%\end{array}$} \\
\hline & & & \\
\hline Do you have any family & No & & \\
\hline $\begin{array}{l}\text { acquaintances, close } \\
\text { relationships which are } \\
\text { openly LGB? }\end{array}$ & Yes & 172 & $43,7 \%$ \\
\hline \multirow{5}{*}{$\begin{array}{l}\text { How do you evaluate } \\
\text { your preparation to } \\
\text { approach sexuality, in } \\
\text { relation to sexual } \\
\text { orientation, with your } \\
\text { students? }\end{array}$} & $\mathrm{Bad}$ & 10 & $2,5 \%$ \\
\hline & Weak & 83 & $21,1 \%$ \\
\hline & Sufficient & 153 & $38,8 \%$ \\
\hline & Good & 126 & $32,0 \%$ \\
\hline & Very Good & 22 & $5,6 \%$ \\
\hline \multirow{2}{*}{$\begin{array}{l}\text { Number of training } \\
\text { courses on sexual } \\
\text { orientation or that have } \\
\text { involved this subject }\end{array}$} & $\begin{array}{l}\text { Average } \pm \\
\text { Standard } \\
\text { Deviation }\end{array}$ & \multicolumn{2}{|c|}{$0,5 \pm 0,9$} \\
\hline & $\begin{array}{l}\text { Median } \\
\text { (Minimum } \\
-\end{array}$ & \multicolumn{2}{|c|}{$0(0-7)$} \\
\hline
\end{tabular}

\begin{tabular}{|l|l|c|c|}
\hline & Maximum) & \multicolumn{2}{|c|}{} \\
\hline $\begin{array}{l}\text { Do you have the } \\
\text { intention to approach in a } \\
\text { school environment } \\
\text { within the scope of } \\
\text { sexual education the } \\
\text { subject of sexual } \\
\text { orientation? }\end{array}$ & No & 171 & $43,4 \%$ \\
\cline { 2 - 4 } & Yes & 223 & $56,6 \%$ \\
\hline $\begin{array}{l}\text { Within the scope of } \\
\text { sexual education in a } \\
\text { school environment, } \\
\text { what is the approximate } \\
\text { frequency that you intend } \\
\text { to approach the subject of } \\
\text { sexual orientation? }\end{array}$ & Daily & 2 & $0,9 \%$ \\
\cline { 2 - 4 } & Weekly & 15 & $6,7 \%$ \\
\cline { 2 - 4 } & Quarterly & 77 & $21,1 \%$ \\
\cline { 2 - 4 } & Annualy & 84 & $33,6 \%$ \\
\hline
\end{tabular}

As for having a family member, close friend or acquaintance who is openly LGB, $43.7 \%$ answered affirmatively. With regard to preparation to address sexuality in relation to sexual orientation with their students, $2.5 \%$ reported this as poor and $21.1 \%$ as weak. $34.3 \%$ of teachers have had training sessions on sexual orientation or training which has involved this subject, and have been to $0.5 \pm 0.9$ sessions on average. In the context of sex education in schools, $56.6 \%$ of teachers intend to address the issue of sexual orientation and of these, $37.7 \%$ intend to address it annually and $33.6 \%$ quarterly.

The results concerning the characterization of the samples regarding positive and negative assumptions about sexual orientation are the following:

The highest level of agreement are those relating to the items "The issues of sexual orientation are transversal to people with or without special educational needs" (82,0\%), "There is a need for further measures/good practices in combating homophobia in schools, for example, in the form of homophobic bullying" (79,2\%), "There is a need to adopt more measures, at a school level, to combat prejudice and discrimination in relation to LGB people" $(71,1 \%)$ and "There is a need to provide more information about lesbian, gays and bisexual people, to reduce prejudice and discrimination in relation to LGB people" $(61,9 \%)$. On the contrary the items "The conjugal protection against domestic violence for same-sex couples makes no sense" $(88,1 \%)$, "Homosexuals and bisexuals should not be blood donors" $(84,0 \%)$, "It is not appropriate to approach sexual orientation in schools as part of sexual education" (79,9\%) and "Civil marriage between persons of the same sex makes no sense" $(68,5 \%)$ are those that have higher proportions of disagreement.

We can say that more than $50 \%$ of teachers have positive views on sexual orientation, except in relation to gay parenting. Similarly, they have, in most cases, adequate knowledge of sexual orientation, in accordance with the literature. However, they reveal inadequate 
knowledge/ignorance of the distinction between sexual orientation and transgenderism, and unfamiliarity with the concept of heterosexism.

\section{Discussion}

The finding that most teachers have, in general, positive views on sexual orientation is consistent with the data presented by the social indicators report 'Society at a Glance 2014' [21] which notes that perceptions of tolerance toward gay and lesbian people grew slightly more positive overall from 2007 to 2012, and increased tolerance was highest in Austria, Norway and Portugal and lowest in Greece, Hungary and Turkey.

However, most teachers have negative opinions regarding gay parenting. This data is consistent with results from Gato and Fontaine [16] and Eurobarometer [17]. However, these negative views constitute a danger and a serious mistake, because there are new family models, including the gay parenting model [5], [15], [16] and the development of children placed in these families does not differ from the development of other children[5],[16]. These negative views could be a stress factor in these individuals' families [16]. One of the first objectives defined for this study was to determine if the variables, gender, age, recruitment group, academic degree, years of service, training sessions in sexual orientation or that have involved this subject, have a close relationship with someone who is openly LGB (lesbian, gay or bisexual), the level of preparedness expressed for the approach to the subject and level of intention to approach the subject are correlated with the assumptions of the teachers 'about sexual orientation.

To put this goal into operation several research hypotheses have been tested and the results may be summarised as follows:

In what concerns the hypothesis "the female teachers have more positive assumptions about sexual orientation than male teachers", this has been validated. There are statistically significant differences $(p<.05)$ between males and females in the items "There is a need to adopt more measures at a school level to combat prejudice and discrimination in relation to LGB persons", "There is a need to provide more information about lesbian, gay and bisexual people to reduce discrimination and prejudice in relation to LGB persons", "There is a need for more measures/ best practices in the combat against homophobia in the school context, for example, in the form of homophobic bullying", "The co-adoption by same-sex couples should be permitted" and "The medically assisted procreation of lesbian couples should be allowed". Female teachers have more positive views on sexual orientation than male teachers, consistent with the findings of studies by Aboin [10] which reveal a greater expression of 'non-heterosexual sexual experience' by females, and Gato [13] which reveals greater inflexibility of males in relation to gender norms. With regard to gay parenting, both sexes express negative views, which is consistent with the Eurobarometer results [17], which state that the majority of the Portuguese population, both female and male, are against the adoption of children by couples of the same sex. This echoes the results of Gato and Fontaine [16], who find a persistence in Portuguese society of the perceived negative effects of gay families on their children's development.

It was not possible, however, to validate other hypothesis that had been placed at the outset, such as: younger teachers have more positive assumptions about sexual orientation; teachers with a higher academic education have more positive assumptions about sexual orientation and special education teachers have more positive assumptions about sexual orientation despite what was expected according to the results of Aboin [10] which enabled to verify that younger women with higher education are more open to non heterosexual experiences, thus suggesting the prevalence in these women of more positive assumptions in regard to homosexuality and bisexuality and also with the results of the Euro barometer [12] that permitted to verify that having a higher education are reasons that lead citizens to become more aware and to avoid discriminatory behaviours, i.e., to have more positive assumptions in relation to sexual orientation.

As to the hypothesis that stated that teachers with less teaching experience would have more positive assumptions about sexual orientation,. We were also unable to confirm that teachers with less teaching experience have more positive views about sexual orientation. However, there was a positive correlation between the length of teaching experience and the statement 'sexual orientation issues cut across people with and without special educational needs.' Despite society as a whole seeing the sexuality of people with disability as something that should be repressed [4], the results of this investigation found that teaching experience plays an important role in recognising possible homosexuality or bisexuality in people with disabilities. These results are consistent with the study by Maia and Aranha [9], which presents teachers reports, based on their professional experience, demonstrating the occurrence of spontaneous behaviour related to gay sex by students with disabilities. However, in this respect, it does not follow the results of Aboin [10], which found that younger women are more open to non-heterosexual experiences, suggesting the prevalence in these women of more positive views on homosexuality and bisexuality. Although teachers participating in this study were mostly female, and teachers with more years of service are usually older, professional experience was a more important factor, 
regardless of age, to having positive views on recognising the diversity of sexual orientations in people with disabilities. In regard to the hypothesis "teachers who participated in training sessions about sexual orientation or that have been involved in this subject have more positive assumptions about sexual orientation", it was not possible to validate, we found the opposite to what was expected, in that in some areas, those who participated in training sessions have more negative views than others. This association is found in the approach to sexual orientation in schools as part of sexual education, gay parenting and same-sex civil marriage. Although Maia and Aranha [9] and Rodrigues [20] suggest that there is a gap in the training of teachers in sex education, in general the training sessions on sexual orientation or which have involved this subject do not succeed in changing participants' views about sexual orientation in a more positive way, compared to those teachers who do not participate in them. It should be borne in mind that the teachers who attended the training could already have more negative views than teachers who did not attend the training and that despite improving their views through training, continued to have more negative views than others. These results do not imply that training made teachers' views worse with regard to sexual orientation. On the other hand, the training may be having some negative effect on these views, even if these views were more negative than in those who did not attend the training. However, one fact that makes it difficult to test this hypothesis is that most of the teachers participating in the study have not had training sessions on sexual orientation or sessions which have involved this subject and also mention this as a major obstacle to approaching sexual orientation in schools as part of sex education. Various issues arise as a result, such as: are these training sessions making teachers' views on sexual orientation worse? Are these training sessions having little impact on improving the teachers' views? Does the audience seeking these training sessions have very negative views and, despite improving their views, continue to have more negative views than those who do not seek this type of training?

As to the hypothesis "the teachers who have a close relationship with someone who is openly LGB (lesbian, gay or bisexual) have more positive assumptions about sexual orientation" it was validated. Teachers who have a close relationship with someone who is openly LGB (lesbian, gay or bisexual) have more positive opinions on sexual orientation, specifically on combating discrimination based on sexual orientation, as well as in relation to gay parenting. These results are consistent with the Eurobarometer results [11], which showed that having a circle of diverse friends and contact with minorities lead citizens to be more alert and have no discriminatory behaviour, as argued by Silva [5], who states that people with less prejudice towards homosexuality are those who come into contact with homosexuals.

As for the hypothesis that claimed that teachers who manifest a higher degree of preparation for the approach to sexual orientation in schools had more positive views on sexual orientation, it was not possible to confirm this. However, it appears that most teachers consider themselves to be prepared to address the issue, although this feeling is contradicted by the fact that they mention their lack of training, knowledge and/or preparation as a major obstacle.

Finally, the hypothesis "teachers who demonstrate a greater degree of intent to approach in a school context as part of sex education, the subject of sexual orientation have more positive assumptions about sexual orientation", it was not validated, because the following results were obtained:

Table 2. Spearman correlation between the frequency of the approach to the theme and the positive/ negative assumptions

\begin{tabular}{|c|c|c|}
\hline \multirow{2}{*}{$\begin{array}{l}\text { 1. The issues of sexual orientation are } \\
\text { transversal to persons with and without } \\
\text { special educational needs }\end{array}$} & $\mathrm{r}$ & $-0,024$ \\
\hline & $\mathrm{p}$ & 0,726 \\
\hline \multirow{2}{*}{$\begin{array}{l}\text { 2. There is a need to adopt more measures, at } \\
\text { school, to combat prejudice and } \\
\text { discrimination in relation to LGB people }\end{array}$} & $r$ & $-0,040$ \\
\hline & $\mathrm{p}$ & 0,561 \\
\hline \multirow{2}{*}{$\begin{array}{l}\text { 3. There is a need to provide more } \\
\text { information about lesbian, gay and bisexual } \\
\text { people, to reduce discrimination and } \\
\text { prejudice against LGB people }\end{array}$} & $\mathrm{r}$ & $-0,015$ \\
\hline & $\mathrm{p}$ & 0,833 \\
\hline \multirow{2}{*}{$\begin{array}{l}\text { 4. There is a need for further measures/good } \\
\text { practices in combating homophobia in } \\
\text { schools, for example, in the form } \\
\text { of homophobic bullying }\end{array}$} & $\mathrm{r}$ & $-0,010$ \\
\hline & $\mathrm{p}$ & 0,887 \\
\hline \multirow{2}{*}{$\begin{array}{l}\text { 5. The age of consent of same-sex couples } \\
\text { should not be equal to the age of consent for } \\
\text { homosexual couples of the opposite sex }\end{array}$} & $\mathrm{r}$ & 0,007 \\
\hline & $\mathrm{p}$ & 0,923 \\
\hline \multirow{2}{*}{$\begin{array}{l}\text { 6. The conjugal protection against domestic } \\
\text { violence for same-sex couples makes no } \\
\text { sense }\end{array}$} & $\mathrm{r}$ & $-0,039$ \\
\hline & $\mathrm{p}$ & 0,569 \\
\hline \multirow{2}{*}{$\begin{array}{l}\text { 7. It is not appropriate to approach sexual } \\
\text { orientation in schools as part of sex } \\
\text { education }\end{array}$} & $\mathrm{r}$ & 0,060 \\
\hline & $\mathrm{p}$ & 0,380 \\
\hline \multirow{2}{*}{$\begin{array}{l}\text { 8. Homosexuals and bisexuals should not be } \\
\text { blood donors }\end{array}$} & $r$ & 0,002 \\
\hline & $\mathrm{p}$ & 0,980 \\
\hline \multirow{2}{*}{$\begin{array}{l}\text { 9. Civil marriage between persons of the } \\
\text { same sex does not make sense }\end{array}$} & $r$ & $-0,029$ \\
\hline & $\mathrm{p}$ & 0,701 \\
\hline \multirow{2}{*}{$\begin{array}{l}\text { 10. Co-adoption by same-sex couples should } \\
\text { be allowed }\end{array}$} & $\mathrm{r}$ & 0,057 \\
\hline & $\mathrm{p}$ & 0,473 \\
\hline \multirow{2}{*}{$\begin{array}{l}\text { 11. Medically assisted procreation for } \\
\text { lesbian couples should be allowed }\end{array}$} & $r$ & 0,109 \\
\hline & $\mathrm{p}$ & 0,179 \\
\hline \multirow{2}{*}{$\begin{array}{l}\text { 12. Medically assisted procreation for gay } \\
\text { couples should not be allowed, with recourse } \\
\text { to surrogacy }\end{array}$} & $\mathrm{r}$ & 0,044 \\
\hline & $\mathrm{p}$ & 0,601 \\
\hline
\end{tabular}


It was therefore not possible to observe any statistically significant correlation $(\mathrm{p} \geq .05)$ between the frequency with which the teachers surveyed intended to address the issue of sexual orientation and the items of positive/negative assumptions.

However, the majority of teachers has the intent to approach the subject of sexual orientation in a school context as part of sex education, this may be due to the fact that the teachers of the Autonomous Region of the Azores feel prepared to approach the subject of sexual orientation in a school context as part of sex education, however, on the other hand, and in contrast a significant part of the teachers indicate a lack of training in sexual orientation as an obstacle to its approach. The intent to approach this subject may also be due to the sense of responsibility and professionalism in fulfilling the obligation of sex education, more specifically, the approach to sexual orientation in a school context as part of sex education granted by recent legislative documents. Nevertheless and in line with the previously mentioned, it should be noted that the majority of teachers intend to approach the subject of sexual orientation with the least possible frequency, this may be related to, for example, the obstacles that manifestly exist to perform it.

With regard to the goal: "describe the obstacles perceived by teachers for the approach to sexual orientation in a school context as part of sex education", we can see the most significant results in Table 3:

Table 3. Obstacles perceived by teachers

\begin{tabular}{|l|c|c|}
\cline { 2 - 3 } \multicolumn{1}{c|}{} & $\mathrm{N}$ & $\%$ \\
\hline $\begin{array}{l}\text { The social and family } \\
\text { environment of the student }\end{array}$ & 135 & $33.9 \%$ \\
\hline $\begin{array}{l}\text { Appropriateness of the } \\
\text { subject to age group }\end{array}$ & 92 & $23.1 \%$ \\
\hline Subject taboo/ prejudice & 84 & $21.1 \%$ \\
\hline $\begin{array}{l}\text { Lack of training/ } \\
\text { knowledge/ preparation }\end{array}$ & 71 & $17.8 \%$ \\
\hline Lack of time & 14 & $3.5 \%$ \\
\hline $\begin{array}{l}\text { Lack of pedagogical } \\
\text { material }\end{array}$ & 10 & $2.5 \%$ \\
\hline Without obstacles & 11 & $2.8 \%$ \\
\hline
\end{tabular}

It appears that the majority of teachers find an obstacle in the approach to sexual orientation in a school context. It is noted that the main obstacle refers to the social environment in which the students are part of, in particular their family environment (33.9\%). Some other obstacles referred to with a relevant frequency were the appropriateness of the subject to age group, cited by $23.1 \%$ of the teachers, it is a taboo subject in which there is some prejudice $(21.1 \%)$ and the lack of knowledge, preparation and training on the part of the teachers $(17.8 \%)$. With less significance in terms of frequency of responses, lack of time $(3.5 \%)$ was also referred and the lack of pedagogical material $(2.5 \%)$. A small proportion of teachers $(2.8 \%)$ reported that there was no obstacle to the approach to sexual orientation in a school context as part of sex education.

These results reveal that the homophobia and heterosexism present in the social environment in which the school operates constitutes the main obstacle encountered by teachers, which meets the suggested by Vilela [18] that says there are obstacles for the approach of human sexuality in a school context by Portuguese teachers, of which, the main is the reaction of others. Nevertheless, the teachers intend to approach sexual orientation in a school context as part of sex education, however, it must be borne in mind that, that intention does not guarantee that the practice is happening or will happen and if it is happening or will happen that it will be done correctly and appropriately.

Finally, with regard to the goal "describe the level of adequate knowledge about sexual orientation that the teachers have, in accordance to the literature", The vast majority of teachers have adequate knowledge of sexual orientation, according to the literature, which contradicts in part the results of other studies reporting the unpreparedness of teachers [3], [9], [18]. However, these studies are contradicted in part, because having knowledge about a subject does not necessarily imply knowing how to put it into practice correctly and appropriately. Apart from the ignorance factor, not knowing how to put their knowledge into practice correctly and appropriately reveals a training gap. There are indications that this is the case, when comparing the results of this research with the aforementioned studies and with the results of the study by Rodrigues [20]. This revealed that while teachers were responding correctly to issues involving sexual orientation, in practice and despite their politically correct discourse, teachers were delivering deficient sex education with regard to issues of sexual orientation, even though they were not aware of it. This thinking is also supported by studies that find that most teachers have a 'conservative attitude' on sexuality [3], [9]. In other words, they favour the reproductive aspects of sexuality and hold contradictory opinions regarding, for example, homosexuality [3]. They may not know how to put their knowledge of sexuality into practice correctly and adequately, including in relation to sexual orientation. While there is a feeling amongst teachers that they are prepared to address sexual orientation in schools as part of sex education, this feeling may not correspond to reality.

\section{Conclusion}

After the completion of this study we can answer the three research questions that acted as a starting point for the development of the goals. In 
regard to the first research question, "what are the factors that are associated to the assumptions of teachers about sexual orientation?", After analysing the results, it can be concluded that the variables that are associated with teachers' views on sexual orientation are gender, length of service, participation in training on sexual orientation or training which has involved this subject, and having a close relationship with someone who is openly lesbian, gay or bisexual.

Most teachers have, in general, positive views on sexual orientation. However, negative views persist in the teaching profession in regard to gay parenting, which risks putting stress on families who come under the gay parenting category. However, female teachers have more positive views on sexual orientation, as do teachers who have a close relationship with someone who is openly lesbian, gay or bisexual. Teaching experience has an important role to play in the recognition of diversity in sexual orientation for people with disabilities. Training for teachers on sexual orientation or training which has involved this subject has in general not managed to make their views on sexual orientation more positive, compared to the views of teachers who did not participate in these sessions. Furthermore, we conclude that factors such as age, academic qualifications, specialisation in special education and preparedness and intention expressed to approach sexual education and the subject of sexual orientation in schools are not associated with teachers' views on sexual orientation. As regards the second and third research questions, respectively, "what is the adequate level of knowledge about sexual orientation that the teachers have according to the literature? and "what obstacles are perceived by teachers for the approach of sexual orientation in a school context as part of sex education?" it was concluded that in general, teachers have adequate knowledge of sexual orientation, in accordance with what is described in the literature as correct. They feel prepared and are intent on addressing the issue of sexual orientation in schools, within the context of sex education. However, they face obstacles in doing this, the largest being extrinsic to themselves; the threat of homophobia and heterosexism that may come from the social and family environment of the student.

It is suggested that sex education on sexual orientation addressed to students and their families should be encouraged, in order to better promote the healthy development of young people in relation to their sexuality. It is also suggested that schools encourage the educational community to engage with positive openly lesbian, gay or bisexual role models.

Schools should train teaching staff and equip a number of male and female educators to be able to address the issue of sexual orientation in schools, as part of sex education. In addition, teachers should be trained in an impartial manner.

Since training sessions on sexual orientation or which include this subject can moderate views and the level of teachers' knowledge on sexual orientation, future research should further explore these phenomena. We urgently need to respond to the following questions: are these training sessions making teachers' views on sexual orientation worse? Are these training sessions having little impact on improving the teachers' views? Does the audience seeking these training sessions have very negative views and, despite improving their views, continue to have more negative views than those who do not seek this type of training?

\section{References}

[1] UNESCO (1994). The Salamanca Statement and Framework for Action on Special Needs Education World Conference on Special Needs Education: Access and Quality. Salamanca, Ministry of Education and Science Spain.

[2] Regional Legislative Decree No. 8/2012/A of 16 March. Official Gazette, 1st series, No. 55.

[3] Albuquerque M. e Ramos, S. (2007). A Sexualidade na Deficiência Mental Profunda: Um Estudo Descritivo Sobre Atitudes de Pais e Profissionais. [Online]. Available at <http://www.psicologia.com.pt/artigos/textos/A0367.pdf> [Retrieved 29/11/2010].

[4] Almeida, M. (2008). A expressão da sexualidade das pessoas com Síndrome de Down, Revista Iberoamericana de Educación, 46 (7/julho), pp. 1-8.

[5] Silva R. (Ed.) (2011). Perguntas e Respostas sobre Orientação Sexual e Identidade de Género. Lisboa, Rede ex aequo.

[6] Kinsey, A. Pomeroy, W. and Martin, C. (1948). Sexual Behavior of the Human Male. Philadelphia, W. B. Saunders Company.

[7] Kinsey, A. Pomeroy, W. Martin, C. and Gebhard, P. (1953). Sexual Behavior of the Human Female. Philadelphia, W. B. Saunders Company.

[8] Freud, S. (1915). Instincts and their Vicissitudes. In: Freud, S. (1996). Complete works. Buenos Aires, Amorrortu, vol. XIV.

[9] Maia, A. e Aranha, M. (2005). Relatos de professores sobre manifestações sexuais de alunos com deficiência em contexto escolar, Interação em Psicologia, 9(1), pp. 103116.

[10] Aboin, S. (2010). Homossexualidade e bissexualidade: práticas, atracções e orientação sexual. In: Ferreira, P. e Cabral, M. (Eds.). Sexualidades em Portugal: Comportamentos e Riscos. 1. ${ }^{\mathrm{a}}$ Edição. Lisboa, Editorial Bizâncio, pp. 147-200. 
Matias \& Silva, 2011).

[12] Eurobarometer (2009). Discrimination in the EU 2009, Eurobarometer 71.2 Results for Portugal. [Online]. Available at http://ec.europa.eu/public_opinion/archives/ ebs/ebs_317_fact_pt_pt1.pdf [Retrieved 22/01/2011].

[13] Gato, J. (2012). Homofobia dos dois lados do atlântico: atitudes negativas face a lésbicas e a gays em Portugal e no Brasil, Passages de Paris, 7, pp. 105-121.

[14] António, R.; Pinto, T.; Pereira, C.; Farcas, D. e Moleiro, C. (2012). Bullying homofóbico no contexto escolar em Portugal. Psicologia, 26 (1), pp. 17-32.

[15] Perelson, S. (2006). A parentalidade homossexual: uma exposição do debate psicanalítico no cenário francês atual, Estudos Feministas. 14 (3/set./dez.), pp. 709-730.

[16] Gato, J. e Fontaine, A. (2010). Desconstruindo preconceitos sobre a homoparentalidade. LES Online, 2 (2), pp. 14-21. [Online]. Available at <http://www.lespt.org/lesonline/index.php?journal=lo\&pa ge $=$ article \&op=view \&path $\% 5 \mathrm{~B} \% 5 \mathrm{D}=34 \&$ path $\% 5 \mathrm{~B} \% 5 \mathrm{D}=$ 33> [Retrieved 22/01/2011].

[17] Eurobarometer (2007). Discrimination in the European Union, Special Eurobarometer 263. [Online]. Available at http://ec.europa.eu/public_opinion/archives/ eb/eb67/eb67_pt_nat.pdf [Retrieved 22/01/2011].

[18] Vilela, C. (2009). A Influência da Família e da Escola na Sexualidade do Adolescente. Coimbra, Formasau Formação e Saúde, Lda.

[19] Foucault, M. (2005). História da Sexualidade I: à vontade de saber. São Paulo, Graal.

[20] Rodrigues, C. (2012). Discursos sobre homossexualidade numa comunidade educativa: perspetivas de professores. Master's dissertation Ponta Delgada, Universidade dos Açores.

[21] OCDE (2014). Society at a Glance 2014, OCDE social indicators. [Online]. Available at <http://dx.doi.org/10.1787/soc_glance-2014-en> [Retrieved 25/04/2014]. 